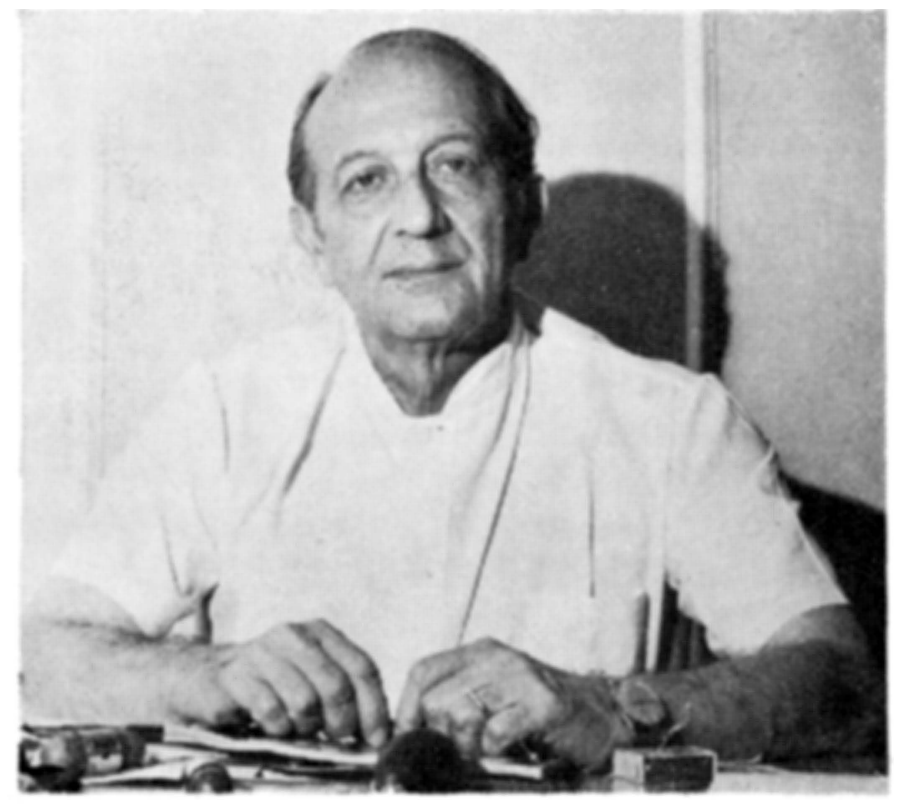

\title{
ANTONIO RODRIGUES DE MELLO
}

(1911-1988)

Na manhā do dia 8 de julho de 1988, quase 15 dias anós ter sido presidente de barica de concurso de tese de doutorado, faleceu, na cidade do Rio de Janeiro, o Prof. Antonio Rodrigues de Mello. Iluminou com vigorosa sapiência, durante várias décadas, a neurologia carioca e fluminense.

Nascido em Campinas, onđe fez seus estudos iniciais, transferiu-se para a cidade do Rio de Janeiro, onde em 1930, iniciou o curso médico, terminado em 1935 . Ainda como interno, comecou a freqüentar a $20^{9}$ Enfermaria, do Prof. Austregésilo, na Santa Casa de Mesericórdia. Daí para diante, sua carreira foi rápida e brilhante. Logo tornou-se assistente voluntário e, após, assistente efetivo da Clínica Neurológica da Faculdad de Medicina da entåo Universidade do Brasil. Assistente predileto do Prof. Austregésilo, a quem acompanhou até a hora final, como seu médico, já em 1943 defende brilhante tese de livre-docência intitulada «Heredo-degeneração cerebelo-espinhal». É considerada obra clássica da literatura médica brasileira, recebendo vários elogios de renomados neurologistas europeus. Em seguida, sua produçāo científica não cessa. Publica numerosos trabalhos em revistas brasileiras e estrangeiras versando sobre assuntos como a síndrome de Adie, a síndrome de Guillain-Barré, a sindrome de Cushing por tumor hipofisário, deficiências vitamínicas e sistema nervoso, mielodisplasia, manifestações neurológicas da eritrofalcemia. Em 1959, ingressa na Academia Nacional de Medicina com o trabalho «Polineuropatia amiloidótica familiar». Em nosso meio, junto com o Prof. Freitas Julião, foi um dos maiores estudiosos desta afecção. Após a apesentadoria compulsória do Prof. Austregésilo, assume a cátedra o Prof. Deolindo Couto. Imediatamente, Mello tornou-se seu Chefe de Clínica e substituto em várias oportunidades, até sua aposentadoria em 1981. Foi laureado com vários prêmios da Academia Nacional de Medicina e com o prêmio Machado de Assis da Academia Brasileira de Letras. Foi um dos fundadores da Academia Brasileira de Neurologia e era membro estrangeiro da Academia Francesa de Neurologia. Em 1976, torna-se, por concurso, Professor Titular de Neurologia da Escola Médica da Universidade do Rio de Janeiro (UNIRIO), passando após a aposentadoria, para Professor Emérito.

A personalidade de Antonio R. de Mello deve ser exaltada, também pelo lado humano. pela nobreza de seus sentimentos. Ele foi antes de tudo um nobre amigo. Encarava discípulos, como se filhos fossem, teve-os em enorme número e de cada um fez um amigo certo. 